\title{
Cold press in oil extraction. A review
}

\section{Büşra Çakaloğlu, Vasfiye Hazal Özyurt, Semih Ötleş}

\author{
Ege University, Bornova, Izmir Turkey
}

Keywords:

Oil

Extraction

Cold

Press

\section{Article history:}

Received 19.05.2018

Received in revised form 12.07.2018

Accepted 27.12.2018

\section{Corresponding author:}

Semih Ötleş

E-mail:

semih.otles@gmail.com

DOI: $10.24263 / 2304-$

974X-2018-7-4-9

\section{Abstract}

Introduction. The aim of this review is to explain the working principle of the cold press machine and discuss the effect of the extraction efficiency. The advantages and disadvantages of the extraction by means of cold press were explained by referring to other extraction methods.

Material and method. The oil extraction from oilseeds by cold press method investigated for this study. The studies related with cold press were examined and the comparison of cold press with other methods used in oil production from oily seeds was compiled.

Results and discussion. Cold press extraction is one of the methods of mechanical extraction as well as required less energy than other oil extraction techniques and also environmental friendly. It is used to extract oil from a range of matrices and is produced especially in the oil production from oilseeds. High-quality oils can be obtained by performing production at low temperatures using cold press method. It has an environmentally friendly use with no solvents. In other words, the cold-press extraction does not involve either heat or chemical extraction. The soybean, sunflower, rapeseed, corn, grapeseed, hemp, flaxseed, rice bran, olive and pumpkin oils were obtained by cold press extraction method. Moreover, these oils are interesting for consumers due to their natural and safe as well as prevent certain diseases and improve human health due to including a higher level of lipophilic phytochemicals such as antioxidants. These oils have better nutritive properties than refined oils. However, they have a lot of advantages, one of the disadvantages of this technique is low productivity. Another disadvantage of this technique is hard to extract same quality product. The cold pressed oils can add to food as natural antioxidative additives due to phytochemicals and as fatty acid supplements due due to invaluabile double bond fatty acid. There are several studies to investigate the other chemical compounds in the oils and try to use in food products.

Conclusion. While observing the studies, it was generally focused on cold press extraction. 


\section{Introduction}

Considering the disadvantages of the solvent extraction method using solvent is toxic and expensive and the damage to the environment is quite excessive, alternative methods of extraction are applied. The desire to obtain high-quality crude oil, ecological reasons and the adaptability of the system to continuous processes are the reasons for the use of mechanical systems [1].

The advantages of mechanical oil extraction include simple use, rapid realization of the process and that leads to the short duration of the process, use of small quantities of raw materials, application of different oilseeds and low cost. Also as a by-product protein, rich press cake is obtained [2].

The disadvantages are that the yield is not as high as the solvent extraction, although it is possible to reduce up to $4-6 \%$ by using pre-heat treated seeds, approximately $7 \%$ of the oil remains in the seed [3].

Mechanical press method is often defined as a solid-liquid phase separation system used for oil extraction from oilseeds with oil content below 20\% [4]. Pressure is used in the separation of the mentioned phase separation. And depending on whether or not the temperature is applied, it is called hot or cold press extraction [5].

Cold press machine has one inlet that seeds were feed and two exits that obtained oil and a non-oiled cake was exit.

Pre-treatment and process parameters applied to the raw material in the cold pressing method play a major role in terms of oil yield. The pre-processes mentioned may be peeling, drying, solvent or enzymatic treatment of raw material; the process parameters are feeding rate, the diameter of the restriction dye, temperature, cold rotation speed $[6,7]$.

Cold presses can be classified as expellers, expanders and twin-cold systems. Twin-cold systems are currently used in laboratory and pilot scale, optimization studies have gained weight. Soybean and cottonseed oil are also used in the production of oil from raw materials that are not considered very high in the amount of oil. Expellers are the name of the first press made by Anderson in 1902. It is the most common type of cold press. In accordance with cold or hot press usage, the heating system has increased the use of being adaptable. The oil separated from the cake is removed from the slot between the metal bars placed at regular intervals with the rotating cold [8].

According to the Turkish Food Codex [9], cold press oils are defined as oils obtained only by mechanical means which are suitable for direct consumption and without heat treatment. In other words, cold pressed oil is generally ready for consumption without needing to be refined, high-quality oil. Many temperature sensitive phenolic compounds are not lost and there are no oxidation reactions occurring along with the heat treatment, which is referred to as a higher quality oil. In the purifying of cold press oils, only washing with water, filtration and centrifugation can be carried out.

In addition to the main functions in human metabolism of vegetable oils, the fact that they are getting much more information about their positive contribution to human health through their bioactive components has led to an increasing interest of consumers in vegetable oils produced by cold pressing and consumed without being refined. Cold press oils with itself characteristic intense taste, color, and special aroma are gaining the appreciation of consumers. Cold press oil production techniques are simple, ecological and do not cost much investment, but the oil yield from raw material is low and the product standard is very difficult to capture $[10,11,12]$. 


\section{Parameters that affect product yield in cold press extraction}

Critical parameters in extraction with cold press; characteristics of the raw material (shell-shellless, moisture content, oil content, and type of raw material), feed rate, temperature (hot or cold), cold rotation speed, the diameter of restriction dye, pre-treatment. In the ongoing paragraphs, the studies which investigated the parameters affecting oil yield in cold press method were located.

Dalgıç et al. [13] studied the effect of the roasting temperature applied to the quality of turbentine oil. For this purpose, 3 different species of Pistacia terebinthus were cleaned from their garbage and mixed homogeneously and pre-dried overnight at $60^{\circ} \mathrm{C}$. Then, turbentine oils were extracted from the menengiç fruit seeds, which were roasted at 100, 120 and 140 ${ }^{\circ} \mathrm{C}$ for half an hour, using a cold press system. Results showed that the oil extraction efficiency, a, $\beta$ and a-tocopherol amounts, palmitic and palmitoleic fatty acid components, total phenolic substance and total chlorophyll, carotenoid and feofitin-a increase due to the increase in roasting temperature. Also, a decrease in oleic and linoleic acid amounts and an increase in acidity, K232, K270 peroxide number was observed. In other words, quality parameters have been negatively affected by higher roasting temperature.

Rabadan et al. [14] aim in this study that determine the effect of cold press extraction temperature on the quality parameters of almond, walnut, and peanut oils. Related the texture of raw materials there is necessary pre-treatment as peeling and drying applied. The effect of cold press extraction conditions (temperature of the device and rotation speed of the cold) on the temperature of the obtained oils were studied. The researchers carried out extraction experiments at $50,100,150$ and $200^{\circ} \mathrm{C}$ temperature and $17,49,96 \mathrm{rpm}$ cold rotation speeds. When the results were examined, it was observed that (when study conditions were $100{ }^{\circ} \mathrm{C}$ and above) the temperature of the oil obtained decreases as the rotation speed increased. The researchers claim that as the rotation speed increased can cause decrease the time that of heating ring exposure. They also found that the temperature of the oil obtained did not exceed $84^{\circ} \mathrm{C}$ even if the ring was raised to $200^{\circ} \mathrm{C}$ so that the temperature of the heating ring had an effect on the oil outlet temperature but the rotational speed was the decisive factor.

Rombaut et al. [15] aimed to investigate the effects of cold press extraction on grape seed oils total phenolic content and optimize the oil yield. Grape seeds obtained from different harvest times were dried up to $7 \%$ moisture content at $40{ }^{\circ} \mathrm{C}$. Materials and process parameters effect determined by Taguchi experiment design with 12 experiments. Variables are a grape seed, pre-heating temperature, rotational speed (20-110 rpm) and restriction dye $(8,10,12$ and $15 \mathrm{~mm})$. Obtained oils were centrifuged at $3000 \mathrm{~g}$ for 10 minutes and moisture, ash, total phenolic contents were determined. Researchers concluded that the most effective parameter due to the determining grape seed oil phenolics is the type of the seeds. Nevertheless, by optimizing the device conditions, it was stated that the number of phenolic compounds would increase, but the increase at the moisture content in raw material had a negative effect on performance.

Burg [16] aimed evaluation of grape seed oil extraction process and 3 white (Welschriesling, Green Veltliner, Hibernal) and 2 red (Zweigelt ve Saint Laurent) grape seeds used for oil production. All seeds moisture and oil contents, 1000 grain weight, density were determined. Seeds were dried about $5-8 \%$ moisture contents at $40^{\circ} \mathrm{C}$. Variables for cold press extraction were grape varieties, rotational speed (20, $406080 \mathrm{rpm})$, press performance and oil yield. Press performance increase as the rotational speed was an increase but oil yield was decreased. Results of this study showed that extraction 1000g seeds can produce 67.5- 98.5 $\mathrm{g}$ seed oil and this approved oil yield has related with seed varieties. 
Hazelnut, pistachio, walnut, apricot, caju, peanut, almonds, pecan walnut samples were dried and waited at $+4{ }^{\circ} \mathrm{C}$ until analysis. Extraction was performed in cold press device with 2-6 liters/H capacity. The oil obtained was left to collapse for 1 week and was recovered from the impurities by applying filtration and kept in the hermetic closed brown bottle under nitrogen gas at $+4{ }^{\circ} \mathrm{C}$. In the solution extraction (petroleum ether) 5 hours extraction time was determined and rotary evaporator $50{ }^{\circ} \mathrm{C}$ was flipped. The oil obtained was preserved in brown glass bottles at $-18{ }^{\circ} \mathrm{C}$. Carotenoid, flavonoid, anthocyanin, fatty acid composition, tocopherol content, total phenolic content, phenolic content composition, antioxidant activity analysis were applied to obtained oils. The oleic acid contents of the cold pressed oils were higher than the oils extracted by Soxhlet method. According to the results of the analysis, the cold press method was compared with soxhlet method and it was argued that the cold press method was a more economical and safe method since it does not include the use of solvents and heat treatment. In addition to different extraction methods, the parameters affecting the quality and yield of fats; raw material type, origin, harvest time, agro-technical precautions [17].

The researchers investigated the influence of pretreatment as cooking and moisture content over the crambe seed oil by cold press extraction. Crambe is a plant species that is commercially used in the industry. Industrial oil containing the high percentage of erucic acid in the seed is commercially important. The plant is produced in the USA, Canada, Italy, and Spain and is included in the radishes class. Crambe seeds are kept at $4{ }^{\circ} \mathrm{C}$ at dry weight with a moisture value of $9.9 \%$. Some of the samples are first cooked and then dried up to the desired moisture content, while others are only dried before the cooking process is applied. In cold compression, the heating ring is set to $120^{\circ} \mathrm{C}$ and the rotational speed is $20 \mathrm{rpm}$. Cold press operation took about four-five minutes. The analysis was made to determine the moisture and fat values of the seeds, and the analysis applied to the oils is the calculation of sedimentation and oil recovery. Results showed that the cooking pretreatment has a positive effect over oil yield but moisture content has a negative effect [18].

In this study which carried out by Akın [19] the contents of fatty acids, phytosterols, squalene, phenolic compounds and acids, carotenoids and phenolic bioactive substances and free radical scavenger antioxidant activities were determined from the raw pumpkin seeds grown in four different central Anatolia regions of Turkey. The oils extracted with cold press extraction method at $40 \mathrm{rpm}$ and $40{ }^{\circ} \mathrm{C}$ were drained and left to collapse for 1 day at the temperature below $15^{\circ} \mathrm{C}$ (sedimentation) in brown bottles, then sedimentation was removed and centrifuged for 20 minutes at $10{ }^{\circ} \mathrm{C}$ and kept at $+4{ }^{\circ} \mathrm{C}$ (refrigerated) until analysis. Results showed that the cold press extraction one of the best method for obtaining quality and solvent-free pumpkin seed oil.

32-factor experimental design was used for almond and walnut oil extraction. Experimental designs include Seed Moisture Content (SMC) and restriction die (Rd) as parameters. Analysis of response variables oil yield (OY), fine solid content (FC) and oil quality parameters. Almond and walnut moisture and oil quantities are determined. All trials were carried out at $35-40{ }^{\circ} \mathrm{C}$ with a rotational speed of $20 \mathrm{rpm}$. The applied analysis was; peroxide value, FFA content, K232 and K270 coefficients, fatty acid composition, oxidative stability with rancimat. RSM was used in oil extraction. Results were showed that SMC has a positive effect on oil yield when $\mathrm{Rd}$ has a negative effect [20].

Singh et al.[21], examined the effect of pre-treatment on the extraction efficiency of linseed oil with the help of the cold press. In this respect, some of the linseeds were only established and some of them were subjected to steam pre-treatment and some to enzyme pre-treatment. Oil yield, residual oil in the cake, rotational speed rate and sediment content were measured as a function of pretreatments and moisture content for cold pressing of 
linseed. Results showed that the pretreatments had a significant effect on residual oil and press rate, no significant effect on oil recovery and sediment content. The researchers find out that the seed which low moisture content has provided better oil recovery from enzyme and steam pretreatments.

In the study of Teh [22], tomatoes, grapes and pomegranate seeds examined the parameters that affect oil extraction by cold press method. The parameters studied within the study are; pre-heating conditions, particle sizes, cold rotation speed, the moisture content of seeds and diameter of restriction dye. It has been concluded that the oil is barely separated from the seeds without pre-heating and the device is heated and facilitates the oil outlet when waiting for a certain period of time. When the effect of particle size was examined, the best result was achieved in the processing of seeds as a whole. As the cold rotational speed increases. Press capacity and speed increases. However, oil efficiency was found to be higher at low cold rotational speeds because of the contact time with the device is more. When the effect of different sizes on oil yield was examined using restriction dye, it was concluded that lower diameter molds increased the oil output (with high pressure) in the seed structure. Moisture content negatively affected oil yield.

\section{Other studies related with cold press extraction}

There are lots of studies related with the cold press extraction. It is hard to classify these studies into groups. But here we mentioned different aimes and how these studies done. Several researchers investigate the different seed cultivars effect on the oil yield;

Walnut oils obtained from 3 different walnut varieties by cold press extraction with 30 rpm rotational speed and $50{ }^{\circ} \mathrm{C}$ temperature. Also, 5 different walnut oils purchased from markets. In this way, 8 different walnut oils have been analyzed for characterization. Moisture, ash, oil, tocopherol, total phenolic contents, antioxidant activity (DPPH, ORAC), volatile content (SPME), pigment (chlorophyll carotenoid), color values (L, a, b) were determined [65]

8 different grape varieties have been chosen and all grape seeds were dried $5-10 \%$ moisture content. Cold press extraction process parameters were flow rate (constant) and rotational rate $40 \mathrm{rpm}$. Seeds moisture and oil contents were determined. Also, total oil contents determined by the solvent extraction method. Obtained oils fatty acids analyzed with gas chromatography [66]

This study [47] was conducted to determine the physicochemical properties of pomegranate seed oils obtained by cold pressing with Torche Malas Iran (TMOI) type and two commercial oils of Iran (COI) and Turkey (COT). Analysis of pomegranate seeds was the determination of moisture, fat, protein, carbohydrates and ash. Thermal properties (DSC), refractive index, determination of viscosity, color values, peroxide value, iodine value, amount of non-anhydrous substance, free fatty acid quantity, total phenolic substance amount, fatty acid composition composition, rapid gas chromatography - surface acoustic wave (GC-saw) and flavor assessment analysis were carried out with obtained pomegranate seed oils.In this study [67] quality and physicochemical properties of 7 different flaxseed oils sold in the market were analyzed. Fatty acid content, moisture content, volatile components, non-saponifying content, free fatty acids, chlorophyll pigment, total phenolic acid and flavonoids, tocopherol composition, color values, peroxide value, conjugated dienoic acids, K230-K270 values were determined. Statistical analysis was performed. The results were compared in accordance with the literature and the law.

Volatile components of grape seed oil obtained from different grapes were investigated. Grapeseed oil was purchased from the market. With solid phase micro-extraction (SPME), 
volatile components were determined in GC/MS. Tag (triacyl glycerol) composition, total phenol content, antioxidant capacity determination (TEAC) was performed [69].

Several researchers tried to optimise the process conditions, add pretreatment for increase the oil yield.

Rice germ oil obtained from the mechanical press. Specific roasting temperatures and durations have been tried, the samples have been prepared as a control. Determination of color, fatty acid composition, phosphorus and phospholipid analysis, $\gamma$-Oryzanol content, tocopherol, and tocotrienol analysis were applied to the obtained oil [68].

In order to perform sesame oil extraction by using Box-Behnken design $\left(50{ }^{\circ} \mathrm{C}\right.$ at low temperature), the cold press extraction method was optimized. Experimental designs include Seed Moisture Content (SMC), pressing speed (PS) and restriction dye (Rd) as the main processing parameters. Cold-squeezing was carried out first on a pilot scale and then on an industrial scale. Pilot-scale; seed moisture content (SMC 7, 12 and 17\% w.b), press speed (PS 20, 40 and $60 \mathrm{rpm}$ ); restriction dye (rd 4, 5 and $6 \mathrm{~mm}$ ). Industrial-scale experimental design includes SMC (8-14\% w.b), PS (20-40 rpm range) and RD (10-14 mm) parameters. The fat content of sesame seeds and pressed cakes were determined by using Soxhlet devices, as solver with $\mathrm{n}$-hexane extraction (10 hours). The solvent was removed at $40{ }^{\circ} \mathrm{C}$ using a rotary vacuum vaporizer. Fat content was determined as gravimetric and expressed as percentages by weight on the dry basis (AOCS 2009). The oil obtained by cold press extraction method was subjected to centrifuge for $11000 \mathrm{~g}, 30$ minutes. Finally, the analysis applied to the oil obtained; peroxide value, free fatty acid value, K232, K270 values, GC help to determine the composition of fatty acid, total lignan content, radical scavenger capacity (DPPH), determination of oxidative stability by rancimat. The pilot plant-scale extraction showed a peak in oil efficiency (or, $71.1 \pm 2.8 \%$ ) at $12.3 \%$ SMC, $4 \mathrm{~mm}$ Rd, and $20 \mathrm{rpm}$ PS. In order to evaluate the proposed extraction method on an industrial scale, theoretical models were scanned against experimental data. A model fitted for oil recovery showed a maximum estimated value similar to the highest experimental value $(74.4 \pm 1.2 \%)$ under the following conditions: 8,03 SMC, $10 \mathrm{~mm}$ Rd and $20 \mathrm{rpm}$ PS. The chemical quality parameters of both pilot and industrial oils have been in the ranges specified in Codex (FAO/WHO) standards for unrefined sesame oil [70].

Several researchers aimed to obtain different oil and their characterization.

Parry [71]; cold pressed onions, parsley, cardamom, cattle, roasted pumpkin, and milk thistle seed oils were taken from the outside. Fatty acid, carotenoid compositions were determined, tocopherol profile was examined, total phenolic matter quantity, ORAC, DPPH, oxidative stability, refractive index, and density analysis were performed.

Siger [72]; antioxidant properties of soybean, sunflower, rapeseed, corn, grapeseed, hemp, flaxseed, rice bran, olive and pumpkin oils obtained by cold press extraction method were studied. Methanol extracts were obtained by solid phase extraction and separation. These oils were purchased from the market. Total phenolic content, determination of phenolic acids (HPLC), antioxidant activity with DPPH were performed.

\section{The role of cold press in food production different than the oil extraction from oil seeds}

Although cold press method is widely used in the oil extraction, there is an area where it is used too much to be underestimated, it is fruit juice production. Different methods such as diffusion method or different press types are also possible to produce juice. However, since we decided to examine the use of only cold presses under this heading of our study, we found 
it appropriate to give information about the screw pressing place during the production phase of fruit juice.

The fruit mass obtained with the crushing of the mill takes the name of mayşe or cake. It is possible to produce clear and fuzzy fruit juices by pressing the cake.

In fruit juice production, screw presses, packaged presses, tape presses, pneumatic presses are used. Cake and press auxiliary material (only if necessary) enters the press feed input, at this stage with the help of sieve free juice leaves and the remaining cake starts to be pressed with the rotating screw. There is a much softer material than the oil extraction from the oil seeds, and there is a possibility that the screw will return to its shape together. To prevent this, press sets have been placed. Thus, the efficiency of this advance has been achieved. The last thing to do is to get out of the restriction dye, water in the structure of the cake is gone and no longer called cake. Here the cake is subjected not only to pressure, but to friction and buckling forces [23].

In addition, pekmez production, wine production, is also used in the production of pestil or in other words fruit leather. These products are produced by juice which obtained cutting and pressing treatments of fruit and than juice concentrated (pekmez), fermenting (wine), concentrated and dried (fruit leather/ pestil) [24, 25, 26].

Different Press types can be used depending on the physical structure of the fruit during pressing stage; it is common to use screw presses because it is suitable for hard fruits such as apples and allows many fruits to be pressed.

\section{The other techniques for oil extraction from seed}

Oil extraction based on basic principles like not damage the oil during the operation, oil extraction with the least possible impurity, reduction of the amount of fat remaining in the cake, to obtain as much oil as possible from the raw material [27]. The principles mentioned are common to all extraction methods, although their technologies are different. Figure 1 in below schematize the basic methods for oil extraction from oilseed materials. In the scope of the study the oil extraction methods, working principles of them and the studies related with them were mentioned and compared with the cold press method which is the main subject of this review.

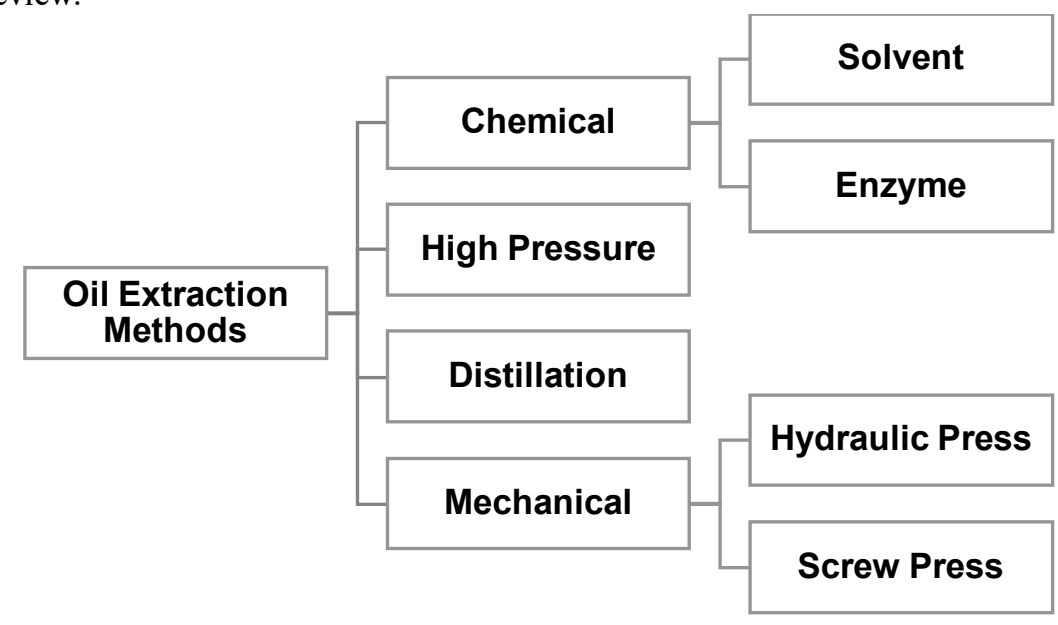

Figure 1. Basic oil extraction methods [28]. 


\section{- Food Technology $\longrightarrow$}

\subsection{Solvent extraction}

First solvent extraction was carried out in France in 1855, Deiss used carbon disulfide as solvent [29]. Although a large number of different solvents are used over time, hegzan is commonly used as a solvent.

Solvent extraction has a multicomponent solid, a solvent which solves the desired material in the medium. The principle of this extraction method is to dissolve the oil with solvent and remove it from the environment. Diffusion is slow in solids, so it is very difficult to reach equilibrium in this process [30].

The parameters affecting solvent extraction are the contact of oil with solvent (oil is usually localized between cells, therefore the size reduction pre-treatment is required, so the surface area is increased, the contact area is also increased), the structure and amount of solvent to dissolve oil, the solution can easily be removed from the environment (lower boiling points ones preferred), temperature (diffusion rate increases as temperature increases) [31].

The advantages of solvent extraction are low cost, simple equipment use, no need to filtration the oil obtained, and high efficiency. However, the too much toxic solution to release the environment and high-temperature application disadvantages [32].

Pradhan et al. [34] examined the chemical composition of the oil obtained from the flax seed with supercritical carbon dioxide extraction, solvent extraction and cold press method. According to this, the highest oil yield was achieved in solvent extraction with hegzan, followed by supercritical $\mathrm{CO}_{2}$ extraction and the minimum efficiency was achieved by cold press method. However, when the quality criteria were examined, the quality of the oil obtained by cold press method was considered to be better than the other techniques. The difficulty of removing the solvent from the oil, the presence of the solvent in the obtained oil, and the fact that it is ecologically harmful, reduces the use of solvent extraction. Instead, the eco-friendly supercritical $\mathrm{CO}_{2}$ and cold press method should be considered. However, when evaluated in terms of yield, supercritical $\mathrm{CO}_{2}$ extraction method can be used between cold press and solvent extraction.

Y1lmaz and Gökmen [35] obtained oil from the seed by solvent extraction in their study for the characterization of sour cherry kernels. In addition, they obtained oil by supercritical fluid extraction method and examined the effect of these extraction methods on the composition of the cherry kernel oil. The results of the study showed that the amount of carotene extracted in solvent extraction was higher and the amount of phenolic compounds was lower. In addition, the effect of hexan and hexan ethanol mixture on oil composition was investigated in solvent extraction and it was observed that oil has a positive effect on the extraction of phenolic compounds, antioxidant activity and carotene composition.

Studies have shown that the solvent extraction method in low and medium fat seeds provides higher oil yield by $11.5 \%$ compared to cold press method $[36,37]$.

\subsection{Enzyme-assisted extraction}

The disadvantages of solving extraction have resulted in the search for alternative methods. Water has been tried as a cheap and non-toxic solvent in order to eliminate the use of toxic solvents. However, no acceptable yield was achieved. On the other hand, with the addition of enzyme, the cost increased more than when the cell wall was broken and the extraction of oil was performed and high efficiency was achieved. Water is used as a separation medium by using the rule that the oil is not dissolved in water, the cell walls are 
broken and the oil extraction is performed so that the amount of enzyme used is reduced as much as possible $[38,39,40]$.

Enzymes used in the aforementioned method have an effect on those in their own structure from the components that make up the cell wall, such as cellulose, hemicellulose, lignin, pectin compounds [41].

The Table 1 shows the enzymes used for enzyme-assisted aqueous extraction from some oilseeds.

Enzymes used for enzyme-assisted aqueous extraction

Table 1

\begin{tabular}{|c|c|c|}
\hline Materials & Used enzymes & References \\
\hline Ground peanuts & Alcalase & {$[42]$} \\
\hline & As1398 & \\
\hline & Protizyme & \\
\hline & Papain & \\
\hline & Chymotrypsin & \\
\hline & Nutrias & \\
\hline & Protamex & \\
\hline Ground sesame seeds & Trypsin & {$[43]$} \\
\hline & Alcalase 2.4L & \\
\hline & Protex 7L & \\
\hline & Viscozyme L & \\
\hline & Natuzyme & \\
\hline Minced yellow horn & Kemzyme & \\
\hline seed kernels & Cellulase & {$[44]$} \\
\hline & Hemicellulase & \\
\hline & Pectinase & \\
\hline Jatropha seed kernels & Protizyme & {$[45]$} \\
\hline & Cellulase & \\
\hline & Pectinex Ultra SP-L & \\
\hline & Promozyme & \\
\hline Watermelon seeds & Protex 6L & {$[46]$} \\
\hline
\end{tabular}

Arslan [47] used an enzyme-assisted aqueous extraction method to extract grape seed oil. According to this, it is proven that the enzyme type, enzyme concentration, hydrolysis time and solvent effect to oil yield and optimum conditions are reached to maximise oil yield.

Jung [48] obtained fat from soybean seeds by aqueous extraction method and enzymeassisted aqueous extraction methods. The cold press method, which is thought to have an effect on oil yield, was pre-treated and its effect on the said extraction was investigated. Accordingly, it was revealed that a greater amount of oil was obtained from the samples subjected to cold pressing as the pretreatment. In particular, the efficiency of cold press was increased from 62.8 to $95.7 \%$ in enzyme-assisted aqueous extraction.

Szydłowska-Czerniak et al. [49] applied to enzyme support to increase the efficiency of cold press method in the extraction of flax seed oil. It was concluded that enzymatic extraction increased the oil yield from 5 to $16.4 \%$. 
Cold press method; simple to use, environment-friendly and fatty seeds are the most commonly used method in the oil field, but its efficiency is low while enzyme-assisted extraction is high but difficult in terms of cost and processing steps are difficult. For these reasons, enzyme extraction can be applied as a pre-process [50, 51, 52, 49].

\subsection{High-pressure extraction}

In this study, high-pressure extraction is relatively new technology than other extraction methods which mentioned. Contrary to popular belief, it is not a homogenization method or supercritical fluid extraction [53].

In high-pressure extraction, the solid samples are usually used and the solution is discharged to high temperatures up to $200^{\circ} \mathrm{C}$ above the boiling point by the short-term highpressure application. Mentioned high pressure to reduce solvent consumption is about 10001500 psi [54].

The advantages are that the obtained product is far away from impurities, that it saves energy, that it is a safe method and that it reduces the use of solvents as much as possible [55, 56].

The difference between the pressure inside and outside the seed cells is based on the principle of breaking the cell wall and the release of the localized oil between them. Therefore, it can be considered as a suitable method for oil extraction from oilseeds. Contact with the solvent can sometimes be interrupted by blocking the solvent passage from the pores with the amount of air and water sample has, but this problem can be solved by applying higher pressure [57, 58].

Previous studies indicate that reducing the emulsion capacity of proteins with high pressure increases the yield of fat extraction. This change in the structure of proteins is facilitated by hydrolysis and denaturation, which is possible with the high-pressure application. With decreasing protein solubility, in addition to denaturation, peptide bonds in proteins facilitate hydrolysis with proteolytic enzymes. This has lead to studies that use the high-pressure method as a pretreatment [59].

Jung and Mahfuz [60] performed enzyme extraction after high-pressure application and increased soybean oil yield by up to $3 \%$.

Andreou et al. [61] studied the effect of high pressure and pulsed electric fields on oil yield and oil quality parameters in olive oil. According to this, the high pressure application of olive oil has increased oil yield by 6 to $8 \%$ (although it varies according to Olive cultivars). The researchers pointed out that the high pressure application did not cause any negative effects on the sensory properties and quality parameters of olive oil, even better caused an increase in oxidative stability of the oil and emphasized that its use in the oil industry with its advantages such as low processing times and low costs could have positive results.

\subsection{Distillation}

Distillation method is a commonly used method in the extraction of essential oils. Aromatic plants contain highly volatile components and therefore, in other extraction methods, a large portion of these components are lost. In distillation, volatile oils released from the plant's structure together with Steam have transported through steam again. When they pass through the back cooler, it intensifies and returns to the liquid form. Thus, it is possible to obtain pure essential oil. Most important advantages of essential oil obtained by steam distillation is that process temperature lower than $100^{\circ} \mathrm{C}$, so included essential oils temperature sensitive other materials can be distilled $[28,62]$. In this study we focused on 
oil extraction from oilseeds, for this reason, it is considered appropriate to give only brief information about distillation method.

\subsection{Hydraulic press}

First in $1785 \mathrm{~J}$. Bramah discovered hydraulic press for oil extraction from oilseeds. In the 1800 's, hydraulic presses with 16 press boxes and 400 tons of pressure force were used [29]. The principle of Hydraulic Press is that the oil that comes out of the filter is obtained by pressing the seeds that are filled in the filter cloth inside the boxes. Press cake remains in filter cloth, then manually emptied. The most important parameters are pressure and temperature [63]. Although the hydraulic press cages that did not require filter cloth in the 1900 s provided great convenience, in 1950, methods such as cold extractors, solvent extraction, which were able to be applied to continuous systems, maintained high-efficiency, worked faster, required less labor, and the remaining oil amounts were relatively low begin to use. The hydraulic press is still used in olive oil production today.

Gros et al. [33] in their study of the purpose of obtaining the oil from flax seed in cold press method used in their work. In order to increase the oil yield, subjected the flax seeds to the hydraulic press as pretreatment but concluded that there was no significant effect on the yield.Owolarafe et al. [64] compared the hydraulic press and cold press method in palm oil extraction. The yield and quality parameters of the oils obtained by these two extraction methods were compared. According to this, it is suggested that the cold press method is superior to the hydraulic press, because the required labor force and cost are lower during the process, oil yield is higher and the processing time is shorter, in other words extraction is faster and obtained oil has better quality.

\section{Conclusion}

In this review, brief information about oil extraction was given and traditional extraction methods were evaluated in terms of advantages, disadvantages and working principles. Since extraction is a very wide and has a very long history separation method, it is limited to working oil extraction and especially with the help of cold press cold squeezing or cold pressing. Cold press is preferred due to its wide usage areas, simple use, lack of manpower, low cost, environmentally friendly, lack of harmful organic solvents and high-quality production possibilities. In addition, generally the product is not applied to heat treatment (cold press), therefore, as mentioned in the study, high-quality oils are obtained. These oils are generally suitable for direct consumption and do not require refining. In this review, the studies which are working on the optimization of the oil extraction with the cold press and the parameters affecting the oil quality and efficiency, and the studies that have applied the pre-treatment before the cold press and examines the effect of the pre-treatment on the oil yield are included. Generally, when the amount of seed moisture content is $10 \%$ and above, the efficiency is negatively affected, the product type has a significant effect on the yield, contrary to the thought that the speed of the cold rotation does not increase the yield. 


\section{References}

1. Richter B. E., Jones B. A., Ezzell J. L., Porter N. L., Avdalovic N., Pohl C. (1996), Accelerated solvent extraction: A technique for sample preparation, Analytical Chemistry, 68, pp. 1033.

2. Singh J., Bargale P. C. (2000), Development of a small capacity double stage compression cold press for oil expression, Journal of Food Engineering, 43(2), pp. 75-82.

3. Arslan M. (2010), Üzüm çekirdeklerinden enzim destekli sulu ekstraksiyon yöntemi ile yă̆ eldesi. Doctoral dissertation, İstanbul Technical University.

4. Zuorro A., Lavecchia R., Medici F., Piga L. (2014), Use of cell wall degrading enzymes for the production of high-quality functional products from tomato processing waste, Chemical Engineering Transactions, 38, pp. 355-360.

5. Kiritsakis A.K. (2002), Virgin olive oil composition and its effect on human health, Inform., 13, pp. 237-241.

6. Savoire R., Lanoisellé J. L., Vorobiev E. (2013), Mechanical continuous oil expression from oilseeds: a review, Food and Bioprocess Technology, 6(1), pp. 1-16.

7. Chemat F., Strube J. (Eds.). (2015), Green extraction of natural products: theory and practice, John Wiley \& Sons, pp. 108-113.

8. Uitterhaegen E., Evon P. (2017), Twin-cold extrusion technology for vegetable oil extraction: A review, Journal of Food Engineering, 212, pp. 190-200.

9. T.G.K., (2012), Türk Gıda Kodeksi Bitki Adlyla Anılan Yağlar Tebliği, Tebliğ no: 2012/29.

10. Matthaus, B. and Brühl, L. (2003), Quality of cold-pressed edible rapeseed oil in Germany, Food, 47(6), pp. 413-419.

11. Gürpınar G.Ç., Geçgel Ü., Taşan m., (2011), Soğuk presyon tekniği ile üretilen bitkisel yă̆ların özellikleri ve sağlık üzerine etkileri. 7. Gida Mühendisliği Kongresi, Ankara.

12. İmer Y., Taşan M., (2018), Çeşitli soğuk pres yağların bazı mikro ve makro element içeriklerinin belirlenmesi, Tekirdăg Ziraat Fakültesi Dergisi, 15(1), p. 15.

13. Dalgıç L., Sermet O. S., Özkan G. (2011), Farklı kavurma sıcaklıklarının menengiç yă̆ kalite parametreleri üzerine etkisi, Academic Food Journal/Akademik GIDA, 9(3), pp. 26-36.

14. Rabadán A., Pardo J. E., Gómez R., Álvarez-Ortí M. (2018), Influence of temperature in the extraction of nut oils by means of cold pressing, $L W T, 93$, pp. 354-361.

15. Rombaut N., Savoire R., Thomasset B., Castello J., Van Hecke E., Lanoisellé J. L. (2015), Optimization of oil yield and oil total phenolic content during grape seed cold cold pressing, Industrial Crops and Products, 63, pp. 26-33.

16. Burg P., Mašán V., Rutkowski, K. (2017), Evaluation of the pressing process during oil extraction from grape seeds, Potravinarstvo, 11(1).

17. Al Juhaimi F., Özcan M. M., Ghafoor K., Babiker E. E., Hussain S. (2018), Comparison of cold-pressing and soxhlet extraction systems for bioactive compounds, antioxidant properties, polyphenols, fatty acids and tocopherols in eight nut oils, Journal of food science and technology, 55(8), pp. 3163-3173.

18. Singh K. K., Wiesenborn D. P., Tostenson K., Kangas N. (2002), Influence of moisture content and cooking on cold pressing of crambe seed, Journal of the American Oil Chemists' Society, 79(2), pp. 165-170.

19. Akin G., Arslan F. N., Elmasa S. K., Yilmaz I. (2018), Cold-pressed pumpkin seed (Cucurbita pepo L.) oils from the central Anatolia region of Turkey: Characterization of phytosterols, squalene, tocols, phenolic acids, carotenoids, and fatty acid bioactive compounds, Grasas $y$ Aceites, International Journal of Fats and Oils, 69(1), pp. 232.

20. Martínez M. L., Bordón M. G., Bodoira R. M., Penci M. C., Ribotta P. D., Maestri D. (2017), Walnut and almond oil cold-press extraction at industrial scale: Effects of process parameters on oil yield and quality, Instituto de la Grasa; Grasas y Aceites, pp. 68-4.

21. Singh K. K., Jhamb S. A., Kumar R. (2012), Effect of pretreatments on a performance of cold pressing for flaxseed, Journal of Food Process Engineering, 35(4), pp. 543-556. 
22. Teh H. E. (2016), Extraction and characterization of functional components from fruit and vegetable processing waste. Ph.D. thesis, University of California, Davis.

23. Cemeroğlu B. S. (2013), Meyve ve Sebze İşleme Teknolojisi. 1. Cilt, 5. Baskı. Ankara.

24. Batu A., Kaya C., Çatak J., Şahin C. (2007), Pestil üretim tekniği, Teknolojik Araştırmalar, Gıda Teknolojileri Elektronik Dergisi, 1, pp. 71-81.

25. Genç S. (2017), Endüstriyel Pekmez Üretim Sürecinde Enerji Analizi, Akademik Gıda, 15(1), pp. 51-59.

26. Özdemir S. (2017), Farklı maya suşlarının narince ve papazkarası (vitis vinifera) üzüm çeşitlerinden üretilen şarapların kaliteleri üzerine etkileri. Master's thesis, Namık Kemal Üniversitesi, Tekirdağ.

27. Ionesu M., Vladut V., Ungureanu N., Dinca M., Zabava B. S. Stefan, M. (2017), Methods for oil obtaining from oleagınous materials, Annals of the University of Craiova-Agriculture, Montanology, Cadastre Series, 46(2), pp. 411-417.

28. Sar1 P., (2006), Preliminary design and construction of a prototype canola seed oil extraction machine, Doctoral dissertation, Middle East Technical University, Ankara.

29. Kirschenbauer H. G., (1944), Fats and Oils, Reinhold Publishing, New York, pp. 122-123.

30. McCabe W.L., Smith J.C., Harriott P. (2001), Unit operations of chemical engineering (6th Edition), McGraw-Hill, Singapore.

31. Balcıoğlu, (2015), Kabak çekirdeğinden enzimatik sulu ekstraksiyon ile yağ eldesi ve yanıt yüzey yöntemiyle optimizasyonu. Masters thesis. İstanbul Technical University.

32. De Castro M. L., Priego-Capote F. (2010), Soxhlet extraction: Past and present panacea, Journal of Chromatography A, 1217(16), pp. 2383-2389.

33. Gros C., Lanoisellé J. L., Vorobiev E. (2003), Towards an alternative extraction process for linseed oil, Chemical Engineering Research and Design, 81(9), pp. 1059-1065.

34. Pradhan R. C., Meda V., Rout P. K., Naik S., Dalai A. K. (2010), Supercritical $\mathrm{CO}_{2}$ extraction of fatty oil from flaxseed and comparison with screw press expression and solvent extraction processes, Journal of Food Engineering, 98(4), pp. 393-397.

35. Y1lmaz C., Gökmen V. (2013), Compositional characteristics of sour cherry kernel and its oil as influenced by different extraction and roasting conditions, Industrial crops and products, 49, pp. 130-135.

36. Aguilera J.M. (2003), Solid-Liquid Extraction. Extraction optimization, in: Food Engineering. Tzia, C. and Liadakis, G. (eds.), Marcel Dekker Inc, New York, USA. pp. 35-55.

37. Kayahan M. (2006), Yağlı tohumlardan ham yă üretim teknolojisi, TMMOB GıdaMühendisleri Odası, kitaplar serisi, 7, Ankara, 244p.

38. Niranjan K., Hanmoungja P. (2004), Nutritionally Enhanced Edible Oil and Oilseed Processing, Chapter 5-Enzyme-Aided Aqueous Extraction, AOCS Press, USA.

39. Moura J. M., Campbell K., Mahfuz A., Jung S., Glatz C. E., (2008), Enzyme-assisted aqueous extraction of oil and protein from soybeans and cream de-emulsification, Journal of The American Oil Chemist' Society, 85, pp. 985-995.

40. Do L. D., Sabatini D.A. (2010), Aqueous extended-surfactant based method for vegetable oil extraction: proof of concept, Journal of the American Oil Chemists' Society, 87(10), pp. 12111220.

41. Wu J., Johnson L.A., Jung S., (2009), Demulsification of oil-rich emulsion from enzymeassisted aqueous extraction of extruded soybean flakes, Bioresource Technology, 100, pp. $527-533$

42. Jiang L., Hua D., Wang Z., Xu S. (2010), Aqueous enzymatic extraction of peanut oil and protein hydrolysates, Foods and Bioproducts Processing, 88, 233e238.

43. Latif S., Anwar F. (2011), Aqueous enzymatic sesame oil and protein extraction, Food Chemistry, 125, pp. 679-684. 
44. Li J., Zu Y. G., Luo M., Gu C. B., Zhao C. J., Efferth T. (2013), Aqueous enzymatic process assisted by microwave extraction of oil from yellow horn (Xanthoceras sorbifolia Bunge.) seed kernels and its quality evaluation, Food Chemistry, 138, 2152-2158.

45. Shah S., Sharma A., Gupta M.N. (2005), Extraction of oil from Jatropha curcas L. seed kernels by the combination of ultrasonication and aqueous enzymatic oil extraction, Bioresource technology, 96(1), pp. 121-123.

46. Sui X., Jiang L., Li Y., Liu S. (2011), The research on extracting oil from watermelon seeds by aqueous enzymatic extraction method, Procedia Engineering, 15, pp. 4673-4680.

47. Khoddami A., Man Y. B. C., Roberts T. H. (2014), Physico-chemical properties and fatty acid profile of seed oils from pomegranate (Punica granatum L.) extracted by cold pressing, European journal of lipid science and technology, 116(5), pp. 553-562.

48. Jung S. (2009), Aqueous extraction of oil and protein from soybean and lupin: a comparative study, Journal of food processing and preservation, 33(4), pp. 547-559.

49. Szydłowska-Czerniak A., Karlovits G., Hellner G., Szłyk E. (2010), Effect of enzymatic and hydrothermal treatments of rapeseeds on quality of the pressed rapeseed oils: part II. Oil yield and oxidative stability, Process Biochemistry, 45(2), pp. 247-258.

50. Rosenthal A., Pyle D. L., Niranjan K. (1996), Aqueous and enzymatic processes for edible oil extraction, Enzyme and Microbial Technology, 19(6), pp. 402-420.

51. Sineiro J., Dominguez H., Nunez M. J., Lema J.M. (1998), Optimization of the enzymatic treatment during aqueous oil extraction from sunflower seeds, Food Chemistry, 61(4), pp. 467-474.

52. Passos C. P., Yilmaz S., Silva C.M., Coimbra M.A. (2009), Enhancement of grape seed oil extraction using a cell wall degrading enzyme cocktail, Food Chemistry, 115(1), pp. 48-53.

53. Shouqin Z., Junjie Z., Changzhen W. (2004), Novel high-pressure extraction technology, International Journal of Pharmaceutics, 278(2), pp. 471-474.

54. Bernal J. L., del Nozal M. J., Jimenez J.J. (1992), Use of a high-pressure Soxhlet extractor for the determination of organochlorine residues by gas chromatography, Chromatographia, 34(9-10), pp. 468-474.

55. Rostagno M.A., Villares A., Guillamon E., Garcia-Lafuente A., Martinez J.A. (2009), Sample preparation for the analysis of isoflavones from soybeans and soy foods, Journal of Chromatography A, 1216(1), 2.

56. Büyüktuncel E. (2012), Gelişmiş ekstraksiyon teknikleri I, Hacettepe Üniversitesi Eczacılık Fakültesi Dergisi, 32(2), pp. 209-242.

57. Bjorklund E., Bowadt S., Nilsson T., Mathiasson L. (1999), Pressurized fluid extraction of polychlorinated biphenyls in solid environmental samples, Journal of Chromatography A, 836(2), p. 285

58. Adil I.H. (2006), Pressurized liquid extraction of phenolic compounds from fruit pomaces. Doctoral dissertation, Middle East Technical University, Ankara.

59. Yusoff M. M., Gordon M. H., Ezeh O., Niranjan K. (2017), High-pressure pre-treatment of Moringa oleifera seed kernels prior to aqueous enzymatic oil extraction, Innovative food science \& emerging technologies, 39, pp. 129-136.

60. Jung S., Mahfuz A. A. (2009), Low-temperature dry extrusion and high-pressure processing prior to enzyme-assisted aqueous extraction of full-fat soybean flakes, Food Chemistry, 114(3), pp. 947-954.

61. Andreou V., Dimopoulos G., Alexandrakis Z., Katsaros G., Oikonomou D., Toepfl S., Taoukis P. (2017), Shelf-life evaluation of virgin olive oil extracted from olives subjected to nonthermal pretreatments for yield increase, Innovative Food Science \& Emerging Technologies, 40, pp. 52-57.

62. Ranjitha J., Vijiyalakshmi S. (2014), Facile methods for the extraction of essential oil from the plant species-a review, International Journal for Pharmaceutical Sciences and Research, 5(4), pp. 1107-1115. 
63. Lanoiselle' J. L., Bouvier J. M., (1994), Le pressage hydraulique des ole'agineux, Mise au point, Rev Franc, Corps Gras, 41(3), pp. 61-72.

64. Owolarafe O. K., Faborode M. O., Ajibola O. O. (2002), Comparative evaluation of the digester-screw press and a hand-operated hydraulic press for palm fruit processing, Journal of food engineering, 52(3), pp. 249-255.

65. Ojeda-Amador R. M., Salvador M. D., Gómez-Alonso S., Fregapane G. (2018), Characterization of virgin walnut oils and their residual cakes produced from different varieties, Food Research International, 108, pp. 396-404.

66. Mašán V., Burg P., Rutkowski K., Burgová J., Lampíŕ L., Višacki V. (2017), Seed oil content and selected qualitative parameters of oils from grape seeds, Potravinarstvo Slovak Journal of Food Sciences, 11(1), pp. 629-633.

67. Choo W. S., Birch J., Dufour J.P. (2007), Physicochemical and quality characteristics of coldpressed flaxseed oils, Journal of Food Composition and Analysis, 20(3-4), pp. 202-211.

68. Kim I. H., Kim C. J., You J. M., Lee K. W., Kim C. T., Chung S. H., Tae B. S. (2002), Effect of roasting temperature and time on the chemical composition of rice germ oil, Journal of the American Oil Chemists' Society, 79(5), pp. 413-418.

69. Bail S., Stuebiger G., Krist S., Unterweger H., Buchbauer G. (2008), Characterization of various grape seed oils by volatile compounds, triacylglycerol composition, total phenols, and antioxidant capacity, Food Chemistry, 108(3), pp. 1122-1132.

70. Martínez M. L., Bordón M.G., Lallana R. L., Ribotta P. D., Maestri D.M. (2017), Optimization of sesame oil extraction by cold-pressing at low temperature, Food and Bioprocess Technology, 10(6), pp. 1113-1121.

71. Parry J., Hao Z., Luther M., Su L., Zhou K., Yu L. (2006), Characterization of cold-pressed onion, parsley, cardamom, mullein, roasted pumpkin, and milk thistle seed oils, Journal of the American oil chemists' society, 83(10), pp. 847-854.

72. Siger A., Nogala-Kalucka M., Lampart-Szczapa E. (2008), The content and antioxidant activity of phenolic compounds in cold-pressed plant oils, Journal of Food Lipids, 15(2), pp. 137-149. 